УДК [378.147:159-051]:005.336.2

DOI:

Елліна Панасенко, доктор педагогічних наук, професор, завідувач кафедри практичної психології Державного вищого навчального закладу "Донбаський державний педагогічний університет"

Світлана Сурчилова, студентка спеціальності "Практична психологія" Державного вищого навчального закладу "Донбаський державний педагогічний університет"

\title{
СОЦАЛЬНО-ПСИХОЛОГІЧНИЙ ТРЕНІНГ В СИСТЕМІ ПІДГОТОВКИ МАЙБУТНІХ ПРАКТИЧНИХ ПСИХОЛОГІВ ЗАКЛАДІВ ОСВІТИ: ПРИНЦИПИ ТА СТРАТЕГІЇ ПОБУДОВИ ПРОГРАМ
}

У статті розглянуто соціально-психологічний тренінг як систему активної підготовки практичних психологів закладів освіти до майбутньої професійної діяльності. Проведено аналіз теоретичних праџь вітчизняних та зарубіжних науковців-психологів, який свідчить, що важливою перевагою соиіальнопсихологічного тренінгу є використання навчального ефекту групових взаємодій $і$ реалізація принципу активності його учасників. Визначено основні функиії соціально-психологічного тренінгу та принципи його побудови. Представлено провідні стратегії побудови тренінгових програм.

Ключові слова: соціально-психологічний тренінг; тренінгова програма; принципи побудови тренінгу; стратегії побудови тренінгу; методика проведення соціально-психологічного тренінгу; функиії соиіальнопсихологічного тренінгу.

Лim. 10.

Ellina Panasenko, Doctor of Sciences(Pedagogy), Professor of the Practical Psychology Department, Head of the Practical Psychology Department State Higher Educational Establishment "Donbas State Teacher's Training University"

Svitlana Surchylova, Student of Specialty "Practical Psychology" State Higher Educational Establishment "Donbas State Teacher's Training University"

\section{SOCIO-PSYCHOLOGICAL TRAINING IN THE PREPARATION SYSTEM OFTHE FUTURE PRACTICAL PSYCHOLOGISTS OF EDUCATIONALINSTITUTIONS: THE PRINCIPLES AND STRATEGIES OF PROGRAM DEVELOPMENT}

The article considers the socio-psychological training as a system of active training of the practical psychologists of educational institutions for their future professional activity. We have analyzed the theoretical works of domestic and foreign scientists-psychologists which show that the important advantage of the social-psychological training is the use of the educational effect of group interactions and the implementation of the principle of the activity from its participants. The task of social and psychological training is defined as the acquisition of knowledge in the field of psychology of the personality and group; the formation and development of communication skills, the correction and development of the personality, the formation, correction and development of facilities for successful communication, the development of the ability to properly comprehend and evaluate yourself, other people, as well as relationships between people. The functions of social psychological training are determined as the assistance to the students for revising their own psychological picture of the professional activity, for comparing it with ideal models; creation of conditions that facilitate the development of the professional competences, development of readiness for professional creativity; promotion of the process of own creative personal and professional growth; ensuring the growth of linguistic, psychological knowledge, skills and abilities; adjusting if necessary, certain elements of the psychologist's activity; the formation of positive relationships and behavior in the group. The basic principles of the designing training programs are considered as the principle of creating a motivational microenvironment, the principle of creating a reflexive microenvironment, the organizing principle of the search-heuristic microenvironment, the principle of free choice and without value judgments, the principle of adequate level of difficulty, the principle of educational problem situations, the principle of alternation of logical and heuristic activity, the principle of the thinking activation components, the principle of continuity, the principle of information enrichment. Strategies of the designing the training programs are presented as the combinatorial strategy, the analog search strategy, the reconstructive action strategy, the universal strategy, the strategy of random substitutions or spontaneous actions.

Keywords: socio-psychological training; a training program; the principles of training; the strategies of training; a method of designing the socio-psychological training; the functions of socio-psychological training.

П остановка проблеми. Реформування системи вищої освіти в Україні підвищуе вимоги до фахових компетентностей практичних психологів, що передбачає високий рівень їхньої соціально-психологічної підготовки. На сучасному етапі розвитку українського 


\section{СОЦАЛЬНО-ПСИХОЛОПІЧНИЙ ТРЕНІНГ В СИСТЕМІПДГОТОВКИМАЙБУТНІХПРАКТИЧНИХ ПСИХОЛОГІВ ЗАКЛАДІВ ОСВІТИ: ПРИНЦИПИ ТАСТРАТЕГІЇ ПОБУДОВИ ПРОГРАМ}

суспільства перед психолого-педагогічною наукою стоять важливі та відповідальні завдання удосконалення навчально-виховного процесу у вищій школі відповідно до проблем нового суспільного розвитку. Розв'язання цих завдань вимагає дослідження проблем, пов'язаних 3 покращенням якості навчально-виховного процесу у закладах вищої освіти. У зв'язку з цим особливого значення набуває вивчення чинників, які впливають на весь хід навчально-виховного процесу та його ефективність.

Аналіз основних досліджень і публікацій. Сучасна психолого-педагогічна наука і практика приділяють значнуувагу соціально-психологічному тренінгу. Фундаментальні праці Н. Богомолової, Ю. Смельянова, Г. Ковальова, Л. Петровської, А. Хараша присвячені питанням підвищення соціально-психологічної компетентності практичних психологів закладів освіти засобами соціально-психологічного тренінгу з метою психолого-педагогічної підготовки фахівців до ефективної праці. Вітчизняні та зарубіжні дослідники (Н. Богомолова, А. Золотнякова, Л. Петровська, Т. Яценко та ін.) використовують соціально-психологічний тренінг для удосконалення навчально-виховної діяльності у вищій ланці освіти.

Метою статті $\epsilon$ обгрунтування значення соціально-психологічного тренінгу в системі підготовки майбутніх практичних психологів закладів освіти та розкриття принципів і стратегій побудови тренінгових програм.

Виклад основного матеріалу дослідження. Сучасна система підготовки практичних психологів закладів освіти, визнаючи обмеженість традиційних підходів до навчання, водночас зберігає дидактичний характер навчання шляхом інформування і розширення знань в галузі психології i педагогіки. Засвоєнню i цілеспрямованому використанню різноманітних знань із загальної, вікової, педагогічної, соціальної, практичної психології заважає своєрідна неусвідомлювана фіксація майбутніми практичними психологами інформації відповідно iз своїм власним досвідом. Подолати це допомагають різні активні форми навчання, зокрема, соціально-психологічний тренінг.

У наукових джерелах соціально-психологічний тренінг потрактовано як систему активної підготовки до спілкування [5]. Метою соціальнопсихологічного тренінгу $є$ підвищення компетентності фахівців у сфері спілкування, удосконалення комунікативної поведінки особистості. Порівняно з іншими методами навчання у вищій школі, перевагами соціально- психологічного тренінгу виступає його здатність слугувати цілям навчання i можливість переводити ці реальні цілі в реальні результати.

У вітчизняній психології фундаментальною передумовою для побудови стратегії і тактики соціально-психологічного тренінгу є принцип діяльнісного опосередкування. Виходячи з логіки діяльнісного підходу соціально-психологічна реальність детермінована практичною діяльністю. Але це не єдиний чинник впливу на психологію особистості і групи. Вплив на груповий розвиток через удосконалення форм міжособистісного спілкування, яке здійснюється в ході соціально-психологічного тренінгу, також $\epsilon$ шляхом оптимізації соціально-психологічних характеристик [8].

Дослідниця Л. Петровська форми соціальнопсихологічного тренінгу розподіляє на дві групи: 1) орієнтовані на розвиток спеціальних умінь, які можна класифікувати за трьома сферами спілкування: комунікативні, перцептивні та інтерактивні; 2) орієнтовані на поглиблення досвіду аналізу ситуацій загалом [8].

Навчальний ефект групової взаємодії у соціально-психологічному тренінгу визначається тим, що:

- група сама стає моделлю для вивчення соціально-психологічних явищ і своєрідною лабораторією формування комунікативних умінь;

- не тренер передає готові знання учасникам, а інформація передається від одного учасника до іншого, тобто кожен може розглядатися як “учитель” відносно іншого, між ними створюються стосунки рівності або змінного домінування учасників, залежно від того, хто в даний момент має необхідну інформацію;

- у групі як посереднику між індивідом і суспільством формується і розвивається особистість індивіда, завдяки групі він вчиться способам задоволення своїх потреб [10].

Отже, головною особливістю соціальнопсихологічного тренінгу є активне оволодіння соціально-психологічними знаннями і навичками. Принцип активності студентів реалізується через включення в навчання елементів дослідження $[2,173]$.

Завдання соціально-психологічного тренінгу стосуються як особистості, так і групи. Традиційно завданнями тренінгу вважаються:

1) одержання знань в галузі психології особистості і групи;

2) формування і розвиток навичок спілкування;

3) корекція і розвиток особистості;

4) формування, корекція і розвиток установок для успішного спілкування;

5) розвиток здатності адекватно сприймати i 


\section{СОЦІАЛЬНО-ПСИХОЛОГІЧНЙ ТРЕНІНГ В СИСТЕМІПДГОТОВКИМАЙБУТНІХПРАКТИЧНИХ ПСИХОЛОГІВ ЗАКЛАДІВ ОСВІТИ: ПРИНЦИПИ ТАСТРАТЕГІЇПОБУДОВИПРОГРАМ}

оцінювати себе самого, інших людей, а також взаємовідносини між людьми [10].

У різних видах соціально-психологічного тренінгу центральною стає якесь певне завдання або група завдань, однак у ході занять реалізуються й інші завдання, оскільки процес спілкування носить цілісний характер, то і соціально-психологічний тренінг необхідно розглядати як цілісну систему.

Важливою перевагою соціально-психологічного тренінгу є використання навчального ефекту групових взаємодій і реалізація принципу активності студентів-учасників через включення в навчання елементів дослідження взаєморозуміння. Учена Л. Петровська вважає, що “якщо традиційні методи орієнтовані переважно на те, щоб довести готові знання, то тут учасники-дослідники самі повинні прийти до них" $[8,104]$.

У психологічній практиці найбільш складною $\epsilon$ проблема визначення методологічної основи i принципів побудови тренінгових програм.

Принципи виконують функцію формування найбільш загальної стратегії, правила визначають приватні тактики різних видів діяльності і самовиховання особистості. Основні принципи програми тренінгу нерозривно пов'язані із загальнодидактичними. Реалізація психологопедагогічних принципів зумовлена соціальним замовленням, вимогами сучасної психологопедагогічної діяльності, а також потребами практичного психолога закладу освіти [4].

В основу побудови соціально-психологічного тренінгуможуть бути покладені такі принципи [1].

Принцип створення мотиваційного мікросередовища. Для проведення тренінгових занять потрібне занурення в діяльність, захоплення цим процесом та виклик своєрідного “потоку”. Щоб ввійти в такий стан учасникам тренінгу потрібно мати позитивний настрій, мотивацію досягнення, вміння підтримати відповідний фокус та концентрацію уваги на діяльності, прагнення до розв'язання важких завдань, оптимальних стосовно їхнього рівня і їхніх здібностей. Саме тому при конструюванні тренінгових вправ психолог повинен ставити перед кожним учасником індивідуальні завдання, орієнтовані на їхні можливості та цілі. Це підвищує мотивацію та інтерес у процесі тренінгу. Психолог заохочує і підкріплює досягнення учасників, порівнює його не з результатами інших, а з його власними, побудованими на минулих успіхах i невдачах 3 індивідуальними стандартами. Підсумком подібних стратегій в тренінгу є зростання привабливості успіху, впевненості у своїх силах. Саме така діяльність може заохотити самостійність учасників, викликати прояв оригінальності, ініціативи, інтелектуальної гнучкості, винахідливості та новизни.

Принцип створеннярефлексивногомікросередовища. Реалізація такого принципугрунтується на створенні деяких умов: в мисленні - створення критичного настрою і пошук загального обгрунтування для аналізу ідей; в діяльності - створення цільових установок, які мотивують учасника до дій при реальній відсутності засобів досягнення цілей цієі ідеї; організація дій з контролю і самоконтролю, оцінки і самооцінки; в спілкуванні - створення відносин кооперації з приводу спільного пошуку основ для оцінки результату і процесу діяльності. Особистісний аспект рефлексивно-діяльнісного принципу спрямований на розвиток здібності до усвідомленого вибору цінностей і формування уявлень про зміст та смислові рамки ситуації [10].

Принцип організації пошуково-евристичного мікросередовища. Евристичне мікросередовище - це спеціально створена у процесі тренінгу ситуація, яка забезпечує появу в учасників потреби в пошуку розв'язання професійних завдань. Учасники тренінгу повинні засвоїти різні способи і прийоми виконання професійної діяльності. Завдяки цьому принципу у фахівців формуються необхідні операційні механізми виконання професійної діяльності - когнітивні та особистісні. Цей принцип забезпечує розвиток оцінювальної функції. Саме завдяки кваліфікованому конструюванню вправ для тренінгу така функція починає сприйматися як універсальний критерій оцінки особистості, створює передумови для самореалізації особистості [10].

Принцип вільного вибору і безоціночних суджень. Ведучий тренінгу повинен дати кожному учаснику свободу вибору та можливість проявляти творчий підхід до справи. Свобода вибору може передбачати право на помилку. Розв'язання проблем може бути ускладнене, якщо учасники будуть критикуватися за помилки або невдачі. Тому в правилах тренінгу повинні бути передбачені положення, які забороняють критику ідей.

Принцип адекватного рівня труднощів. Внаслідок індивідуальних відмінностей в когнітивних стилях людей не всі учасники тренінгу можуть показувати високі результати, пропонувати оригінальні рішення, бути дуже гнучкими, тому для розроблення тренінгових завдань потрібно визначати реальні цілі, виходячи 3 когнітивних здібностей. Цілі, які грунтуються на рівнях власних досягнень, дають відчуття 


\section{СОЦІАЛНО-ПСИХОЛОГІЧНИЙ ТРЕНІНГ В СИСТЕМІПДГОТОВКИМАЙБУТНІХПРАКТИЧНИХ ПСИХОЛОГІВ ЗАКЛАДІВ ОСВІТИ: ПРИНЦИПИ ТАСТРАТЕГІЇ ПОБУДОВИПРОГРАМ}

впевненості, компетентності, що позитивно впливає на підвищення ймовірності досягнення успіху.

Принцип навчальних проблемних ситуацій. Навчальні проблемні ситуації сприяють формуванню і закріпленню фахових умінь, викликають потребу долати труднощі, адже “проблемна ситуація - вихідний момент продуктивного мислення, джерело і стимул пошукової пізнавальної активності і творчої діяльності людини" [9, 34]. Проблемні ситуації варто підбирати зі сфери професійної діяльності фахівця або з реального повсякденного життя. Це забезпечить варіативний пошук розв'язання проблем, дасть змогу гнучко застосовувати набуті знання, дозволить ретельно розробляти задумані ідеї.

Принцип чергування логічної й евристичної діяльності застосовується для того, щоб в учасників тренінгу не формувався стереотип виконання одноманітної роботи за конкретними правилами. Потрібно розвивати у студентів здатність творчо підходити до вирішення проблем, але при цьому слідувати логіці, висувати реалістичні рішення [4].

Принцип активізації компонентів мислення полягає у потребі розвивати у людини здатність не звертати увагу на зовнішні перешкоди, а, отже, формувати уміння зосереджуватися, розвивати фантазію, уяву; позбавлятися від відсталості мислення; не боятися ризикувати і пробувати; мати адекватну самооцінку.

Принцип спадкоємності припускає безперервний логічний перехід від теми до теми, підведення підсумків роботи, зворотний зв' язок.

Принцип інформаційного взаємозбагачення. Творча самоактуалізація - це процес, який припускає, що кожного разу, роблячи вибір, людина здійснює його на користь особистісного зростання. Це поняття, на думку А. Маслоу, охоплює розвиток творчого і духовного потенціалу майбутнього практичного психолога, максимальну реалізацію всіх його можливостей, адекватне сприйняття оточуюючих, світу і свого місця в ньому, багатство емоційної сфери і духовного життя, високий рівень психічного здоров'я і моральності [6].

Зміст соціально-психологічного тренінгу спрямований на формування пізнавальних здібностей, комунікативної компетентності, становлення творчих властивостей особистості практичного психолога закладу освіти. Розвиває не саме знання, а спеціальне його конструювання. Зміст - це те, що повинне бути засвоєне. Зміст єдність всіх елементів об’єкта, їх відносини тощо.
У тренінгу формується ставлення до навчального предмету і педагогічного процесу як до засобу самореалізації, розвитку себе, що створює сприятливе підгрунтя для опанування майбутньою професією.

Основна стратегія програм соціальнопсихологічного тренінгу орієнтована на створення можливості для розвитку загальних та професійних компетентностей, готовності до подальшого власного особистісного і професійного зростання на творчій основі. Психологічний механізм реалізації стратегії розгортається в процесі здійснення таких функцій соціальнопсихологічного тренінгу:

1. Надання допомоги студентам ревізувати власну психологічну картину професійної діяльності, зіставити іiї з ідеальними зразками (діагностична функція).

2. Створення умов, які сприяють розвитку фахових компетентностей, вироблення готовності до професійної творчості (стимулююча функція).

3. Сприяння процесу власного творчого особистісного i професійного зростання (розвивальна функція).

4. Забезпечення приросту лінгвістичних, психологічних знань, умінь та навичок (навчальна функція).

5. Коригування у разі потреби певних елементів діяльності психолога (коригувальна функція).

6. Формування позитивних відносин і поведінки у групі (виховна функція) [4].

Методика проведення соціально-психологічного тренінгу спрямована на: а) розгляд всіх відповідей, навіть самих несподіваних, незвичних і дивних, як відповідей цінних, гідних уваги. Під час проведення тренінгу підкреслюється, що не існує “правильних" або “неправильних” відповідей, цінною є будь-яка відповідь; б) підтримку прагнення учасників до пошуку нових i евристичних відповідей; в) створення доброзичливої атмосфери за допомогою емоційної взаємної підтримки; г) використання “дискусійних гойдалок” як засобу колективного пошуку нового, оригінального рішення обговорюваної проблеми [3].

При побудові соціально-психологічного тренінгу серед основних засобів варто застосовувати такі стратегії:

1. Стратегія комбінаторних дій (комбінування) полягає: у зміні розташування мовних деталей в існуючій лінгвістичній конструкції рідною мовою, знаходженні доцільних сполучень, комбінацій; у варіативних поєднаннях технологій, форм і методів навчання. 


\section{СОЦІАЛЬНО-ПСИХОЛОГІЧНИЙ ТРЕНІНГ В СИСТЕМІПІДГОТОВКИМАЙБУТНІХПРАКТИЧНИХ ПСИХОЛОГІВ ЗАКЛАДІВ ОСВІТИ: ПРИНЦИПИТАСТРАТЕГЇ̈ПОБУДОВИПРОГРАМ}

2. Стратегія пошуку аналогів (аналогізування) проявляється у використанні відомих психологопедагогічних технологій в нових змінних умовах освітнього простору.

3. Стратегія реконструктивнихдій (реконструювання) виявляється у перебудові власної системи набуття розширення професійних знань; упереконструюванні психолого-педагогічного інструментарію та введенні нових суттєвих елементів, які значно збагатять набір методичних засобів практичного психолога.

4. Універсальна стратегія передбачає поєднане застосування стратегій аналогізування, комбінування і реконструювання (у більшості випадків найефективніше їх комплексне використання).

5. Стратегія випадкових підстановок або спонтанних дій використовується у ситуаціях невизначеності та непередбачених умов, що виникають упрофесійній діяльності [7].

Висновки. Основне завдання активних методів навчання полягає у формуванні нового стилю спілкування викладачів вищої школи у суб'єкт-суб' єктній взаємодії зі студентами. Важливим завданням соціально-психологічного тренінгу є розвиток соціально-психологічної компетентності, під якою розуміється знання чинників групового спілкування, розуміння стратегї̈ і тактики поведінки партнерів по спілкуванню, володіння технологічними прийомами, а також вміння використовувати їх в конкретній ситуації. Соціально-психологічний тренінг сприяє формуванню психологічних вмінь, тісно пов'язаних 3 розвитком професійних властивостей особистості практичного психолога закладу освіти. У ході соціально-психологічного тренінгу навчання спрямоване на оптимізацію і модифікацію окремих рис особистості майбутнього практичного психолога закладу освіти, комунікативного потенціалу, психокорекцію глибинних особистісних якостей. Навчання сприяє зміні життєвої позиції, установок, розвитку сензитивності, самосвідомості, підвищенню соціально-психологічної компетентності студентів.

\section{ЛІТЕРАТУРА}

1. Бажанюк В. С. Принципи побудови психологічного тренінгу креативності для майбугніх професіоналів / В. С. Бажанюк, Т. В. Стафійчук // Психологічні тренінгові технології управоохоронній діяльності: науково-методичні та організаційнопрактичні проблеми впровадження і використання, перспективи розвитку: Матеріали III Міжнар. наук.-практ. конф. - Донецьк: ДЮІ ЛДУВС, 2007. - C. $150-154$.
2.Емельянов Ю.Н. Активное социальнопсихологическое обучение / Ю. Н. Емельянов. Л.: Изд-во Ленингр. ун-та, 1985. - 167 с.

3. Захаров В. П. Социально-психологический тренинг: учеб. пособ. / В. П. Захаров, Н. Ю. Хрящева. - Л.: Изд-во ЛГУ, 1989. - 55 с.

4. Кашапов М. М. Психология творческого мышления профессионала / М. М. Кашапов. - М.: Персэ, 2006. - 688 с.

5. Краткий психологический словарь: хрестоматия / сост. Б. М.Петров, под. ред. К. К.Платонова. - М.: Высшая школа, 1974. - 459 с.

6. Маслоу А. Мотивация и личность / А. Маслоу. - СПб.: Питер, 2003. - 352 с.

7. Моляко В. А. Психологические проблеми творческой одаренности / В. А. Моляко. - К.: Ово “Знание", 1995. - 52 с.

8. Петровская Л.А. Теоретические и методические проблемы социально-психологического тренинга / Л. А. Петровская. - М.: Изд-во Моск. ун-та, 1982. $-168 \mathrm{c}$.

9. Фурман А. В. Теорія навчальних проблемних ситуацій: психолого-дидактичний аспект: монографія. - Тернопіль: Астон, 2007. - 164 с.

10. Яценко Т. С. Активное социальнопсихологическое обучение: теория, процесс, практика: учеб. пособ. / Т. С. Яценко, Я. М. Кмит, Б. Н. Алексеенко. - Хмельницкий: НАПВУ; М.: СИП РИА, 2002. - 792 с.

\section{REFERENCES}

1. Bazhaniuk, V. S. (2007). Pryntsypy pobudovy psykholohichnoho treninhu kreatyvnosti dlia maibutnikh profesionaliv [Principles of designing a psychological training of creativity for future professionals]. Donetsk: DIUI LDUVS, pp. $150-$ 154. [in Ukrainian].

2. Emelianov, Yu. N. (1985). Aktivnoye sotsialnopsikhologicheskoye obucheniye [Active social and psychological training]. Leningrad: Izd-vo Leningr. unta, 167 p. [in Russian].

3. Zakharov, V. P. (1989). Sotsialno-psikhologicheskiy trening [Social and psychological training]. Leningrad: Izd-vo LGU, 55p. [in Russian].

4. Kashapov, M. M. (2006). Psikhologiya tvorcheskogo myshleniya professional [Psychology of creative thinking of a professional]. Moscov: Perse, 688 p. [in Russian].

5. Petrov, M. B. \& Platonov, K. K. (1974). Kratkiy psikhologicheskiy slovar: khrestomatiya [Briefpsychological dictionary: compilation]. Moscov: Vysshaya shkola, 459 p. [in Russian].

6. Maslou, A. (2003). Motivatsiya i lichnost [Motivation and personality]. Saint Petersburg: Piter, 352 p. [in Russian]. 


\section{IT-МЕТОДИЧНЕ СЕРЕДОВИЩЕПРОФЕСІЙНОӤ ПІДГОТОВКИ МАЙБУТНІХ ФІЛОЛОГІВ: ЗМІСТ ІСУТНІСТЬ ПОНЯТТЯ}

7. Molyako, V. A. (1995). Psikhologicheskiye problemi tvorcheskoy odarennosti [Psychological problems of creative giftedness]. Kyiv: O-vo "Znaniye", 52 p. [in Russian].

8. Petrovskaya, L. A. (1982). Teoreticheskiye $i$ metodicheskiye problemy sotsialno-psikhologicheskogo treninga [Theoretical and methodological problems of socio-psychological training]. Moscov: Izd-vo Mosk. un-ta, 168 p. [in Russian].

9. Furman, A. V. (2007). Teoriia navchalnykh problemnykh sytuatsii: psykholoho-dydaktychnyi aspekt : monohrafiia [Theory of educational problem situations: the psycho-didactic aspect: monograph]. Ternopil: Aston, 164 p. [in Ukrainian].

10. Yatsenko, T. S. (2002). Aktivnoye sotsialnopsikhologicheskoye obucheniye: teoriya. protsess. praktika: ucheb.posob. [Active socio-psychological education: theory, process, practice: training manual]. Khmelnitskiy: NAPVU; Moscov: SIP RIA, 792 p. [in Russian].

Стаття надійшла до редакції 15.05.2018

УДК 378.147:811.111 (081)

DOI:

Наталія Арістова, доктор педагогічних наук, доцент, завідувач кафедри англійської філології Національного університету біоресурсів і природокористування Украйни, м. Київ

\section{ІТ-МЕТОДИЧНЕ СЕРЕДОВИЩЕ ПРОФЕСІЙНОЇ ПЦДГОТОВКИ МАЙБУТНІХ ФІЛОЛОГІВ: ЗМІСТ І СУТНІСТЬ ПОНЯТТЯ}

Автор розглядає авторські підходи до визначення змісту і сутності понять "середовище”, "освітнє середовище”, "IT-освітнє середовище” і надає власне визначення поняття "IT-методичне середовище професійної підготовки майбутніх філологів". Обтрунтовано необхідність створення IT-методичного середовища професійної підготовки майбутніх філологів, щчо включає повне систематизоване зібрання засобів навчально-методичного характеру $i$ уможливлює розвиток студентів філологічних спечіальностейяк суб'єктів професійної життєдіяльності.

Ключові слова: середовище; освітнє середовище; IT-освітнє середовище; IT-методичне середовище професійної підготовки майбутніх філологів; майбутні філологи, заклад вищої освіти.

Jim. 15.

Nataliya Aristova, Doctor of Sciences(Pedagogy), Associate Professor, Head of the English Philology Department National University of Life and Environmental Sciences of Ukraine, Kyiv

\section{IT-METHODICAL ENVIRONMENT FOR THE FUTURE PHILOLOGISTS' PROFESSIONAL TRAINING: A CONTENT AND ESSENCE OF THE CONCEPT}

In the article the essence of the concepts "environment" and "educational environment" is specified. It is found out that Ukrainian and foreign scientists mostly interpret an educational environment as a set of definite conditions, a system, a formation or reality. The author considers the scientists 'approaches to definition of the content and essence of the concept "IT-educational environment" and gives own definition of the concept "IT-methodical environment for future philologists' professional training". The author substantiates the necessity of creation of IT-methodical environment for the future philologists' professional training which includes a total collection of teaching tools and promotes the development of students of philological specialties as the agents of professional and vital activities. Besides, the IT-methodical environment for the future philologists 'professional training helps the teachers to involve students of philological specialties to new kinds of educational activities with the aim of ensuring a professional philological focus of educational content, develop their information culture and motivation of success. IT-methodical environment for future philologists' professional training is defined as an open virtual system, which creation and functioning supplies all participants of educational process by necessary educational, methodical and additional information and promotes realization of creative-potential of students-philologists, formation of their readiness and ability to further professional work. To one of the main conditions of successful functioning of IT-methodical environment for future philologists' professional training we attribute supporting their professional training on the basis of realization of the agent-agent interaction in all paradigmal variations of communication.

Keywords: an environment; an educational environment; IT-methodical environment; IT-methodical environment for future philologists ' professional training; the future philologists; a higher educational institution.

П остановка проблеми. 3 огляду на те, що інноваційні інформаційні технології мають безпосередній вплив на всі сфери життєдіяльності сучасного людства, одним (C) H. Арістова, 2018 iз головних напрямів модернізації системи вищої професійної освіти $є$ їі глобальна інформатизація та створення IT-методичного середовища професійної підготовки майбутніх фахівців взагалі 